\title{
PENGARUH ORIENTASI CSR, SIKAP, DAN KOMPETENSI TERHADAP PERAN KARYAWAN PADA PT BANK PEMBANGUNAN DAERAH JAWA TIMUR TBK SURBAYA
}

\author{
Mufidatus Shelvia \\ Fakultas Ekonomi, Universitas Negeri Surabaya \\ email: mufidatus23@gmail.com
}

\begin{abstract}
This study aims to find out and explain the influence of CSR Orientation, Attitude, and Competence on the Role of Employees at PT East Java Regional Development Bank Tbk Surabaya. This study uses a quantitative approach to employees using the Probability Sampling sample, namely the Proportionate Stratified Random Sampling of 62 employees. Statistical analysis used is Structural Equational Modeling (SEM) through SmartPLS Software version 3.2.8. The results of this study indicate that CSR orientation has a significant positive effect on the Role of Employees, Attitudes have a significant positive effect on the Role of Employees, while Competence does not significantly influence the Role of Employees.
\end{abstract}

Keywords: orientation of CSR, attitude, competence, role of employees

\section{PENDAHULUAN}

Adanya perkembangan teknologi dan persaingan pada dunia industri yang berkembang pesat akan menuntut sebuah perusahaan untuk selalu berkembang dan mengoptimalkan peran atau kinerja karyawan yang dimilikinya. karyawan merupakan elemen yang harus diperhatikan dalam perusahaan, hal itu di karenan karyawan memiliki peran penting bagi keberlangsungan dan keberhasilan perusahaan. Menurut Ismail et al. (2014) peran karyawan dalam pencapaian tujuan sebuah organisasi memiliki pengaruh yang signifikan. Peran dapat meningkatkan minat dalam memahami perusahaan untuk membawa bisnis mereka ke dalam lingkungan global (Ruzgar dan Kurt, 2013).

Riset dari Michigan University Amerika Serikat menyatakan di seluruh dunia konsep peranperan baru profesional sumber daya manusia telah banyak diimplementasikan dan dikenal oleh perusahaan besar di Indonesia (Suryaningtyas, 2013). Ionescu, Merut, dan Dragomiroiu (2014) menyatakan peran dari seseorang dapat merubah organisasi diantaranya adalah komunikator, pendukung, pelatih, lingkungan dan esistensi perusahaan. Saidi et al. (2014) menyatakan peran memiliki empat kunci dari sumber daya manusia yaitu: mitra strategis, agen perubahan, ahli administrasi, dan karyawan.
Adanya peran yang strategis dari pimpinan divisi maupun tim dapat meningkatkan kinerja dari karyawan perusahan (Dikutip dari www.kompasiana.com pada 03 April 2019). Diez, Gago, dan Campillo (2011) menyatakan bahwa tidak mungkin ada perusahaan yang dapat berjalan dengan baik tanpa adanya peran karyawan didalamnya yang bertanggung jawab untuk mencapai tujuan, kepentingan dan kebutuhan perusahaan. Menurut KBBI keterlibatan adalah keikutsertaan individu atau berperannya emosi individu dalam situasi tertentu, maka selanjutnya akan digunakan kata peran dengan menggunakan rumusan dari peran sendiri maupun dengan keterlibatan.

Ketika perusahaan semakin berkembang dan dapat mencapai keberhasilan maka perusahaan dituntut untuk melaksanakan program tanggung jawab sosial (CSR). Kegiatan CSR pertama kali diatur dalam Undang-Undang perusahaan atau UUPT yaitu di Indonesia yang disahkan pada tanggal 20 Juli 2017, dan kemudian diatur secara teknis dalam Peraturan Pemerintah Nomor 47/2012. Scholmerich (2013) menyatakan orientasi CSR adalah "CSR is a sensitising concept" yang dapat menarik perhatian untuk berbagai masalah yang kompleks dan elemen yang semuanya terkait dengan posisi dan fungsi bisnis perusahaan dalam masyarakat yang kontemporer. CSR yang meliputi 
tanggung jawab sosial perusahaan dan keseluruhan kegiatan memiliki banyak manfaat secara sosial.Orientasi CSR merupakan salah satu dasar dalam pemahaman CSR, persepsi seseorang tentang CSR memberikan peran penting dalam keberlanjutan perusahaan (Ismail et al., 2014).

Menurut Jamali (2007) masih belum ada bukti yang empiris tentang peran karyawan yang berkaitan dengan efektivitas CSR. Penelitian tentang CSR telah menerima dorongan yang cukup besar dalam ekonomi barat sementara hanya sedikit atau tidak sama sekali telah terjadi pada negara berkembang, pemahaman tentang CSR hanya di dominasi oleh perspektif Eropa dan AmerikaUtara. Menurut UNDP dalam Ismail et al., (2014) negara-negara barat sudah banyak yang melakukan penelitian mengenai CSR namun sedikit yang berfokus pada Asia. Pada tahun 2010 pelaksanaan CSR di negara Malaysia berada pada peringkat kedua dari Singapura, diantara negaranegara di Asia Tenggara dibandingkan dengan Thailand, Filipina, dan Indonesia.

Realita yang terjadi pada kasus dari adanya program CSR, yang dilaksanakan PT Bank Pembangunan Daerah Jawa Timur Tbk (Bank Jatim) sebagai berikut:

1) Pelaksanaan CSR pada tahun 2014 dibagi kedalam empat bidang yaitu pendidikan, kesehatan, sosial, dan budaya sebesar Rp. 15,47 miliar yang terbagi dalam empat bidang pendidikan, kesehatan, kebudayaan dan sosial

2) Pada Februari 2014 Bank Jatim memberikan bantuan mobil truck kepada perusahaan daerah rumah pemerintah Kota Surabaya.

3) Pada Desember 2016 Bank Jatim memberikan bantuan dengan empat kategori penyaluran yaitu, pendidikan, kebudayaan, kesehatan dan sosial kepada sepuluh Kabupaten/ Kota di Jawa Timur.

4) Pada Januari 2017 Bank Jatim memberikan bantuan kepada PMI Surabaya.

5) Tahun 2017 PT Bank Pembangunan Daerah Jawa Timur (Bank Jatim) menerima penghargaan CSR Award 2017 yang diselenggarakan oleh majalah Economic Review. Dalam pencapaian tersebut tentu saja ada peran dan kerja keras karyawan. Oleh karena itu peran karyawan sangat berpengaruh dalam program CSR.

6) Pada September 2018 Bank Jatim memberikan bantuan kepada pemerintah Kota Surabaya berupa excavator dan dump truck.

Apabila perusahaan ingin tujuan maupun program-program dalam organisasi dapat di- wujudkan, maka dibutuhkan sikap dari karyawan untuk mencapainya. Oleh karena itu sikap karyawan dalam perusahaan dapat memberikan pengaruh terhadap berjalannya sebuah organisasi. Secara empiris bahwa pemimpin yang sukses dibidang lingkungan harus memiliki sikap yang terbuka terhadap perubahan (Egri dan Herman, 2000). Sikap dianggap penting karena dapat menjelaskan keterlibatan emosional dalam kontribusi terhadap isu-isu CSR (Ismail et al., 2014). Sikap kerja dari seorang karyawan dapat dijadikan sebagai bahan ukur apakah seorang karyawan dapat bekerja dengan baik atau tidak.

Newton dan Harte dalam Fernandez et al. (2006) menyatakan sikap manajemen/karyawan tidak memiliki pengaruh dalam praktik nyata dari strategi perusahaan. Berdasarkan observasi yang telah dilakukan pada PT Bank Pembangunan Daerah Jawa Timur Tbk (Bank Jatim) sikap karyawan dalam memberikan pelayanan, kemampuan dalam menjelaskan produk, dan penampilan fisik customer service dapat dikatakan cukup baik, ramah dan sopan.

Selain sikap, kompetensi karyawan juga sangat penting untuk mendukung perusahaan dalam mencapai tujuannya. Kompetensi dapat didefinisikan sebagai keterampilan teknis yang berhubungan dengan produk dan proses perusahaan seperti keterampilan sistem komputer dan pemecahan masalah yang kaitannya dengan dunia digital, kompetensi interpersonal berhubungan dengan kemampuan seseorang untuk berbicara, berdiskusi, berorganisasi dan membujuk klien (Ismail et al., 2014).

Berdasarkan survey yang dilakukan oleh Towers Watson dalam Global Workforce Study (GSW) kepada 1.637 perusahaan termasuk perusahaan Indonesia yang berjumlah 36 menyatakan lebih dari $70 \%$ perusahaan Indonesia yang mengalami kesulitan dalam hal perekrutan dan mempertahankan karyawan yang memiliki kompetensi yang baik (Dikutip dari https://ekbis.sindonews.com pada 25 Maret 2019). Pada kasus lain, perusahaan southwest.com yang berada di Texas Amerika Serikat selalu mengadakan event tahunan yang ditujukan untuk karyawan mereka dan program pengembangan kemampuan untuk meningkatkan kualitas dan kompetensi karyawannya, hal tersebut dilakukan untuk meningkatkan kualitas kerja para karyawannya (Dikutip dari www.cermati.com pada 25 Maret 2019).

Pada kenyataannya PT Bank Pembangunan Daerah Jawa Timur Tbk Surabaya mewajibkan 
seluruh karyawannya untuk memiliki kompetensi yang dibutuhkan pada setiap fungsi organisasi, dan hal tersebut tidak terlepas dari status yang dimiliki oleh karyawan.

Ismail et al. (2014) di dalam penelitiannya pada tahun 2014 yang dilakukan di perusahaanperusahaan Malaysia menyebutkan bahwa studi ini menemukan bahwa tingkat peran, orientasi dan kompetensi manajer CSR tinggi, sedangkan untuk sikapnya sedang. Selanjutnya hasil analisis regresi menunjukkan bahwa orientasi CSR dengan tanggung jawab ekonomi dan etika serta kompetensi secara signifikan dipengaruhi peran mereka dalam CSR dengan kekuatan penjelas dari 20,1 persen.

Alonso dan Austin (2018) dalam penelitiannya menggunakan populasi dari empat perusahaan yang berlokasi di Australia Barat. Hasilnya menunjukkan bahwa secara total, terlepas dari industri dan ukuran perusahaan yang berpartisipasi, keterlibatan dalam kegiatan CSR menunjukkan dorongan dari peserta yang sangat besar, dimana CSR dianggap sebagai tujuan untuk meningkatkan komunitas atau masyarakat mereka, dan pada saat yang sama peluang bisnis menjadi potensial.

Yoon dan Lee (2016) dalam penelitiannya menyatakan pengukuran dua variabel dependen yaitu, keefektifan dan niat untuk meninggalkan, salah satu mediator yaitu, persepsi keaslian CSR, dan dua variabel independen yaitu, atribusi eksternal dan atribusi internal. Hasil dari penelitian ini adalah Efek dari dua variabel atribusi eksternal dan internal pada keaslian CSR adalah signifikan dan efek keaslian CSR pada variabel hasil juga signifikan. Temuan ini mendukung mediasi keaslian CSR. Artinya, atribusi eksternal dan internal mempengaruhi keterikatan afektif karyawan dan niat untuk pergi.

Voermans dan Van Veldhoven, (2007) dalam penelitiannya menyajikan sebuah proyek tentang sikap terhadap peran manajemen sumber daya manusia elektronik (E-HRM). Penelitian ini menghasilkan bahwa sikap dan E-HRM signifikan positif terhadap peran sumber daya manusia.

Kohont dan Brewster (2014) meneliti bagaimana peran dan kompetensi yang dibutuhkan dari manajer sumber daya manusia di perusahaan multinasional Slovenia yang mengalami peruabahan ketika perusahaan-perusahaan ini memasuki arena internasional. Penelitian ini menunjukkan bahwa kompleksitas peran manajer sumber daya manusia, dan harapan dari kompetensi mereka dapat meningkat sesuai dengan internasionalisasi perusahaan. Nansubuga dan
Munene (2013) melakukan penelitian untuk menguji kontribusi yang lebih kuat antara kompetensi (pengetahuan, keterampilan dan sikap) dan kejelasan peran. Hasil penelitian ini menunjukkan bahwa kompetensi berpengaruh secara signifikan positif terhadap kejelasan peran.

\section{Tinjauan Literatur \\ Peran}

Peran karyawan adalah mitra strategis yang melibatkan fokus strategi dan proses yang lebih berorientasi, peran bertanggung jawab dalam merancang organisasi untuk mewujudkan tujuan dan arah dari organisasi.

Ruzgar dan Kurt (2013) menyatakan peran dapat meningkatkan minat dalam memahami perusahaan untuk membawa bisnis mereka dalam lingkungan global

Ismail et al. (2014) menyatakan peran adalah mitra strategis yang melibatkan fokus strategi yang melibatkan strategi dan proses yang lebih berorientasi untuk mewujudkan tujuan dan arah dari sebuah organisasi. Dari pendapat beberapa ahli diatas maka dapat disumpilkan, peran merupakan perilaku yang dimiliki oleh sesorang yang menempati suatu kedudukan dan dapat memberikan pengaruh kepada organisasi untuk mewujudkan tujuan dan arah dari organisasi.

Menurut Fernandez et al. (2006) salah satu indikator dari peran dapat dijelaskan sebagai berikut:

1) Inovator

Dimana pemimpin memiliki kemampuan yang kreatif dalam pemecahan masalah, perubahan dan dapat dengan mudah untuk beradaptasi.

2) Broker

Dimana pemimpin dbertindak sebagai jembatan untuk menjalankan kekuasaan untuk menghubungkan dengan sumber daya.

3) Mediator

Dimana manajer memiliki peran sebagai pengatur konflik dan pengambilan keputusan partisipatif

4) Mentor

Dimana manajer berperan sebagai pengembang sumber daya manusia.

Menurut Alonso dan Austin (2018) peran memiliki lima indikator yang dapat dijelaskan sebagai berikut:

1) Fungsional

Perilaku atau karakteristik orang yang menduduki posisi sosial dalam sistem yang 
stabil secara sosial, dan membantu menjelaskan bagian-bagian yang berbeda dari sistem sosial

2) Interaksi simbolik

Menekankan pada evolusi peran berdasarkan interaksi sosial, dan konsep-konsep kognitif yang berbeda melalui penafsiran dan memahami perilaku orang lain.

3) Struktural

Struktur sosial yang dikonseptualisasikan sebagai organisasi yang stabil dari kelompok orang yang disebut "status" atau "posisi sosial"

4) Organisasi

Tugas yang berorientasi dan sistem sosial yang direncanakan terjadi dalam organisasi adalah inti dari peran yang disebabkan oleh ekspektasi normatif dan terkait dengan posisi sosial. Sumber-sumber dari konflik peran antara individu akan menyababkan ketegangan yang berpotensi negatif, dan individu harus mencari solusi agar organsasi bisa makmur.

5) Kognitif

Hubungan antara perilaku dan peran secara khusus harus diperhatikan untuk kondisi sosial yang mengakibatkan harapan dalam perilaku sosial dan teknik untuk mengukur harapan.

Penelitian ini menggunakan indikator menurut Tjahjono (2006) yaitu: Strategi SDM (Menyamakan strategi dan dengan tujuan bisnis perusahaan adalah peran dari sumber daya manusia), Transformasi dan perubahan (Transformasi meliputi perubahan budaya yang terjadi dalam perusahaan, perubahan mengarah kepada kemampuan untuk menciptakan ide-ide baru atau inspirasi dalam setiap penerapan proses perusahaan), Kontribusi Karyawan (Adanya permasalahan didunia kerja membuat karyawan harus berkontribusi serta peduli dan memperhatikan kebutuhan setiap karyawan. Karyawan), Infrastruktur perusahaan (Insfrastruktur organisasi adalah peran dari tanggung jawab SDM dalam menjalankan proses-proses organisasi secara efektif seperti, staffing, training, hadiah, penghargaan, dan promosi).

Menurut Ahtobara et al. (2013) faktor-faktor yang mempengaruhi peran adalah :

1) Faktor ekternal

a) Keluarga/ keturunan

Sebagai lingkungan pertama dan utama bagi seseorang dipandang memberikan pengaruh yang sangat besar bagi terbentuknya peran.

b) Pendidikan

Kualifikasi pendidikan diduga turut mempengaruhi terbentuknya peran seseorang dalam meningkatkan kualitas hidupnya, termasuk peningkatan peng-hasilan rumah tangganya.

c) Lingkungan masyarakat

Masyarakat merupakan lingkungan ketiga setelah keluarga dan pendidikan yang juga mempengaruhi terbentuknya peran seseorang.

2) Faktor internal

a) Pemahaman

Pemahaman yang baik terhadap suatu hal akan berpengaruh pada tindakan yang diambil dalam menentukan pilihan aktivitas hidup.

b) Kebutuhan

Faktor kebutuhan merupakan keinginan yang berasal dari dalam diri seseorang, bersedia atau tidaknya seseorang untuk melakukan suatu tindakan tergantung pada tujuan sesuai dengan yang diinginkan seseorang.

c) Bakat

Bakat merupakan suatu yang ada pada setiap diri seseorang, oleh karena itu bakat akan berpengaruh pada kecenderungan bertindak seseorang dalam menentukan perannya

\section{Orientasi CSR}

Orientasi CSR adalah suatu bentuk tanggung jawab sosial perusahaan yang kompleks untuk mengembangkan lingkungan sekitar melalui kegiatan atau program-program sosial dari perusahaan yang dilakukan dengan sukarela. Dahlsrud (2008) menyatakan bahwa orientasi CSR merupakan sebuah konsep dimana perusahaan mengintergrasikan kepedulian sosial dan lingkungan operasi bisnis mereka dalam berinteraksi dengan para pemangku kepentingan mereka secara sukarela. Scholmerich (2013) menyatakan orientasi CSR mengacu pada tanggung jawab sosial (lingkungan) perusahaan yang menarik perhatian untuk berbagai masalah yang komplek dan elemen yang semuanya terkait dengan posisi dan fungsi bisnis perusahaan dalam masyarakat.

Duthler \& Dhanesh (2018) menyatakan indikator dari orientasi CSR dapat dinyatakan sebagai berikut:

1) Tanggung jawab ekonomi

Dalam tanggung jawab ekonomi masyarakat mengharapkan bisnis untuk memproduksi barang dan jasa serta dapat menjualnya sehingga akan mendapatkan keuntungan. 
2) Tanggung jawab hukum

Dalam tanggung jawab hukum mengacu pada harapan masyarakat bahwa bisnis yang layak secara ekonomi dalam konteks hukum.

3) Tanggung jawab etis

Dalam tanggung jawab etis mengacu pada jenis perilaku, norma-norma etika, dan praktik dalam bisnis.

4) Tanggung jawab discretionary

Dalam tanggung jawab discresionary membahas aspek sukarela tanggung jawab sosial perusahaan.

5) Tanggung jawab lingkungan

Dalam tanggung jawab lingkungan masyarakat mengharapkan perusahaan harus menjadi perusahaan yang baik.

Carroll and Shabana (2010) menyatakan indikator dari orientasi CSR dapat dinyataan sebagai berikut:

1) Tanggung jawab ekonomi bisnis

Tanggung jawab ekonomi bisnis digunakan dalam menghasilkan barang dan jasa yang dibutuhkan dan diinginkan masyarakat, serta menjualnya dengan profit atau sebagai unit utama ekonomi masyarakat.

2) Tanggung jawab hukum bisnis

Tanggung jawab hukum bisnis mengacu pada kewajiban positif dan negatif menggunkan bisnis oleh hukum dan peraturan dimana perusahaan beroprasi.

3) Tanggung jawab etika bisnis

Tanggung jawab etika bisnis mewujudkan standar-standar, norma, atau harapan yang dapat mencerminkan kepedulian terhadap apa yang konsumen, karyawan, pemegang saham, masyarakat harapkan dari perusahaan.

4) Tanggung jawab filantropis bisnis

Tanggung jawab filantropis bisnis adalah tindakan-tindakan perusahaan yang dalam menanggapi harapan masyarakat bahwa bisnis perusahaan menjadi lebih baik.

Pada penelitian ini indikator yang digunakan untuk mengukur orientasi CSR adalah, economic responsibility (orientasi tanggung jawab ekonomi dianggap penting untuk mempertahankan posisi kompetitif yang kuat bagi perusahaan), philantropis responsibility (dimana orientasi tanggung jawab filantropis dianggap sangat penting untuk dilakukan dengan cara yang konsisten melalui pelaksanaan yang sesuai dengan harapan masyarakat), legal responsibility (orientasi tanggung jawab hukum dianggap sangat penting untuk menjadi perusahaan yang taat dengan hukum), ethical responsibility (orientasi tanggung jawab etis dianggap sangat penting untuk dilakukan dengan cara yang konsisten dengan adat istiadat, sosial, dan norma-norma etika yang sesuai dengan harapan masyarakat).

Menurut Visser (2008) dalam Duthler and Dhanesh (2018) pemikiran CSR dipengaruhi oleh empat faktor utama, sebagai berikut:

1) Adanya perkembangan ekonomi di negaranegara berkembang yang menyebabkan pertumbuhan pasar semakin berkembang pesat dan menguntungkan untuk berbisnis.

2) Adanya krisis sosial dan lingkungan yang paling dirasakan di negara-negara berkembang.

3) Adanya globalisasi, pertumbuhan ekonomi, investasi, dan aktivitas bisnis diharapkan memiliki dampak sosial dan lingkungan. Perkembangan ekonomi menawarkan serangkaian dari tantangan CSR secara kolektif yang dihadapi di negara maju.

\section{Sikap}

Sikap adalah reaksi atau respon diri sendiri terhadap objek tertentu yang dapat bereaksi secara positif atau negatif yang dapat memberikan pengaruh terhadap sekitarnya. Rashid dan Ibrahim (2002) menyatakan adanya tanggung jawab untuk bersikap adil, jujur, dapat dipercaya dan hormat dalam semua urusan. Howe dan Krosnick (2017) menyatakan sikap dapat diartikan dengan mengikat diri sendiri untuk berfikir tentang objek, untuk mengumpulkan informas, menggunakan informasi dalam membuat keputusan yang relevan dalam merancang sebuah tindakan seseorang. Ismail et al. (2014) menyatakan sikap menjelaskan keterlibatan emosional karyawan dan kontribusinya terhadap CSR serta kemampuan karyawan untuk mengidentifikasi peluang yang bersifat internal atau eksternal bagi sebuah organisasi. Sim dan Lee (2018) menyatakan bahwa indikator sikap dapat dibagi menjadi dua yaitu, Kepuasan kerja (Kepuasan kerja adalah keadaan emosional yang dihasilkan dari evaluasi yang positif dari pengalaman saat bekerja), Komitmen organisasi (Komitmen organisasi adalah dimana seseorang telah berpihak kepada suatu organisasi berdasarkan dari internalisasi organisasi seperti nilai atau tujuan).

Menurut Blum and Nylon (2008) dalam Amanto (2011) sikap dipengaruhi oleh beberapa faktor, sebagai berikut:

1) Kondisi kerja

Kondisi kerja yaitu kenyamanan karyawan dalam melaksanakan pekerjaan yang dipengaruhi oleh lingkungan fisik dan sosial. 
2) Pengawasan atasan

Sikap dan semangat kerja dapat dipengaruhi oleh pengawasan dan pelatihan yang dilkukan oleh atasan.

3) Kerja sama dari teman kerja

Adanya kerjasama antara teman dalam bekerja dapat mempengaruhi kualitas dan prestasi karyawan dalam menyalesaikan tugas yang diberikan.

4) Kesempatan untuk maju

Adanya kesempatan untuk berkarir dan tunjangan hari tua menjadikan salah satu motivasi dalam sikap kerja.

5) Keamanan

Ketenangan yang disebabkan oleh rasa aman akan bertambah jika lingkungan sekitar selalu terjaga.

6) Fasilitas kerja

Terciptanya sikap kerja yang baik dapat dipengaruhi oleh fasilitas yang memadai dan cukup.

7) Imbalan

Sikap karyawan dalam melaksanakan maupun menyelesaikan pekerjaannya dapat dipengaruhi oleh rasa tenang dari jumlah gaji pokok, bonus, dan tunjangan yang diberikan.

\section{Kompetensi}

Kompetensi adalah keterampilan atau kualitas yang harus dimiliki oleh seseorang yang dapat membedakan satu individu dengan individu lain yang dilihat dalam konteks pekerjaan atau lingkungannya. Skorkova (2016) menyatakan kompetensi adalah kemampuan manusia untuk berhasil mempertahankan keterampilan, pengetahuan, kemampuan, bakat dan keterlibatan karyawan. Menurut Ismail et al. (2014) kompetensi adalah karakteristik atau faktor seperti motif, sifat dan pola perilaku yang membedakan antara yang lebih unggul dari rata rata. Podmetina et al. (2018) menyatakan kompetensi yaitu keterampilan dan kemampuan yang diperlukan untuk pelaksanaan kegiatan inovasi terbuka dan kolaboratif.

Indikator dari kompetensi menurut Ismail et al. (2014) dapat dibagi menjadi empat yaitu, kompetensi teknis, kompetensi komunikasi, kompetensi kewirausahaan.

Khoshouei, Oreyzi and Noori (2013) menyatakan faktor-faktor dari kompetesi yaitu:

1) Nilai

Nilai dapat diartikan sebagai keyakinan, dan cita-cita bersama oleh individu-individu dari budaya tentang apa yang baik dan apa yang tidak.
2) Analisis

Analisis adalah pemeriksaan rinci dari elemen atau suatu struktur.

3) Pengambilan keputusan

Pengambilan keputusan yaitu mengidentifikasi dan memahami isu-isu, masalah, dan peluang dengan menggunakan suatu pendekatan.

4) Pengetahuan

Pengetahuan menggambarkan informasi dan keterampilan yang diperoleh melalui pengalaman atau pendidikan.

5) Adaptasi

Adaptasi berarti menjaga efektifitas ketika mengalami perubahan besar dalam penyelesaian tugas pribadi atau lingkungan kerja.

6) Kinerja

Adanya tanggung jawab oleh diri sendiri atau orang lain untuk menetapkan tujuan, harapan, kebutuhan dan peluang bisnis.

7) Kepemimpinan

Kepemimpinan adalah gaya interpersonal yang tepat dalam menetapkan metode untuk menginspirasi dan membimbing individu atau kelompok untuk mencapai arah dan tujuan.

8) Komunikasi

Komunikasi yaitu penyampaian dan penerimaan informasi serta ide-ide secara langsung ataupun melalui berbagai media kepada individu atau kelompok.

\section{Kerangka Berfikir}

Berdasarkan dari pemaparan latar belakang diatas, maka kerangka berfikir dapat dijelaskan sebagai berikut:

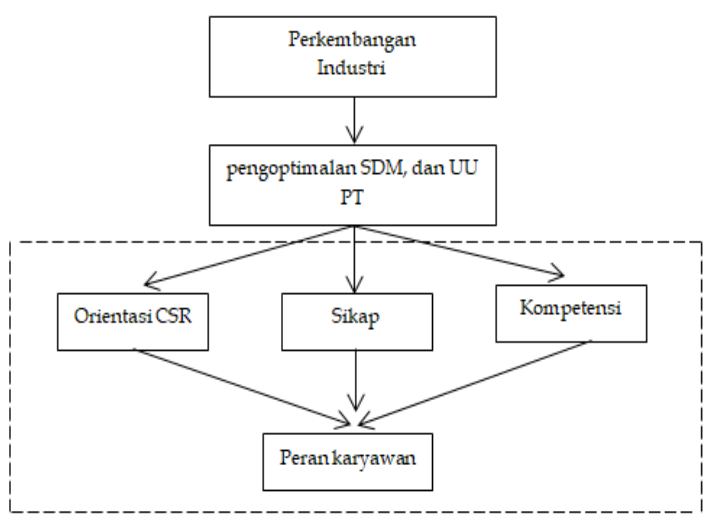

\section{Gambar 1}

\section{Kerangka Berfikir}

Sumber: Diolah oleh penulis

Dengan adanya perkembangan industri yang semakin berkembang pesat perusahaan juga 
dituntut untuk mengoptimalkan sumber daya perusahaannya terutama sumber daya manusisa yang dimilikinya, semakin baik sebuah perusahaan maka profit dan tanggung jawabnya juga semakin besar, tanggung jawab sosial perusahaan telah diatur dalam Undang-Undang perusahaan atau UUPT yang disahkan pada tanggal 20 Juli 2017, dan kemudian diatur secara teknis dalam Peraturan Pemerintah Nomor 47/2012.

Dalam penerapan program tanggung jawab sosial perusahaan (CSR) maka dibutuhkan orientasi CSR yang tepat agar CSR yang dilakukan sesuai dengan tujuan perusahaan, hal itu dikarenakan orientasi CSR merupakan dasar dari pemahaman CSR. Ismail et al. (2014) menyatakan manajemen tanggung jawab sosial perusahaan atau Corporate Social Pesponsibility adalah sumber daya manusia yang profesional yang dapat menghubungkan perusahaan dengan masyarakat. Jika perusahaan ingin mewujudkan tujuan maupun program didalam organisasi dengan baik maka dibutuhkan sikap, dan kompetesi dari karyawan yang baik pula. Oleh karena itu sikap dan kompetensi seseorang karyawan dalam perusahaan dapat memberikan pengaruh terhadap berjalannya sebuah organisasi. Menurut Egri dan Herman (2000) secara empiris bahwa pemimpin yang sukses dibidang lingkungan di tingkat yang lebih tinggi harus memiliki sikap yang terbuka terhadap perubahan.

Selain itu, kompetensi karyawan juga sangat penting untuk diperhatikan karena kompetensi karyawan sangat mempengaruhi berjalannya organisasi. Menurut Podmetina (2018) kompetensi merupakan keterampilan dan kemampuan yang diperlukan untuk pelaksanaan kegiatan, inovasi dan kolaboratif. Karyawan harus memiliki kompetensi yang baik untuk meningkatkan kualitas diri dan juga meningkatkan kualitas perusahaan agar pekerjaan yang dimilikinya dapat berjalan dengan baik dan sesuai dengan tujuan yang dimiliki oleh perusahaan. Keberhasilan dari perusahaan tidak lepas dari adanya peran karyawan yang terlibat didalamnya. Menurut Ismail et al. (2014) terdapat pengaruh yang signifikan antara peran karyawan dalam pencapaian tujuan sebuah organisasi, peran karyawan adalah mitra strategis yang melibatkan fokus strategi dan proses yang lebih berorientasi, peran bertanggung jawab dalam merancang organisasi untuk mewujudkan tujuan dan arah dari organisasi. Jadi kerangka konseptual pada penlitian ini dapat dilihat pada Gambar 2.

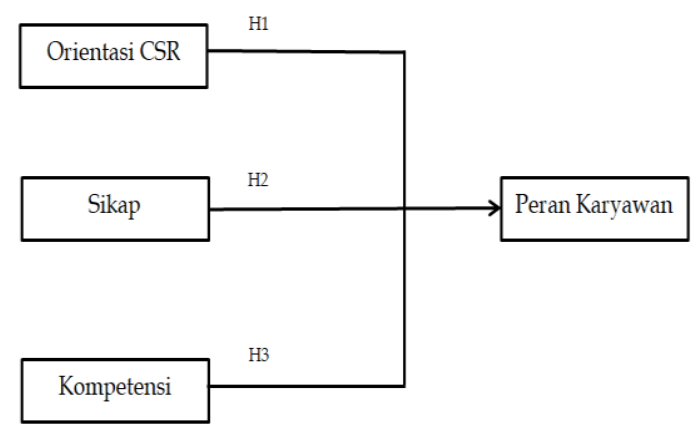

\section{Gambar 1}

Kerangka Konseptual

Sumber: Diolah oleh penulis

Berdasarkan uraian tersebut maka penulis dapat menjadikan semua hal yang telah dijabarkan diatas menjadi hipotesis dari penelitian ini yaitu:

H1 =Diduga orientasi CSR berpengaruh positif terhadap peran Karyawan pada PT Bank Pembangunan Daerah Jawa Timur Tbk Surabaya.

H2 =Diduga sikap berpengaruh positif terhadap peran Karyawan pada PT Bank Pembangunan Daerah Jawa Timur Tbk Surabaya.

H3 =Diduga kompetensi berpengaruh positif terhadap peran Karyawan pada PT Bank Pembangunan Daerah Jawa Timur Tbk Surabaya.

\section{METODE PENELTIAN \\ Populasi dan Sampel}

Jenis penelitian yang dilakukan menggunakan metode kuantitatif. Menurut Ferdinand (2006) populasi merupakan seluruh gabungan dari elemen yang berbentuk peristiwa, hal atau karakteristik seseorang yang menjadi pusat perhatian peneliti karena dipandang sebagai sebuah semesta penelitian. Penelitian ini menggunakan populasi dengan jumlah karyawan PT Bank Pembangunan Daerah Jawa Timur Tbk Surabaya sebanyak 75 pada tiga divisi yaitu Corporate Secretary, Pengendalian Keuangan, dan Kepatuhan dan Tata Kelola. Penelitian ini menggunakan teknik pengambilan sampel Probability Sampling yaitu Proportionate Stratified Random Sampling dimana teknik ini dipilih karena populasi yang digunakan memiliki unsur yang beragam dan berstrata (Sugiyono, 2018). 
Tabel 1

Tabel Penentuan Jumlah Sampel dari Populasi Tertentu

\begin{tabular}{cccc}
\hline \multirow{2}{*}{$\mathbf{N}$} & \multicolumn{3}{c}{$\mathbf{S}$} \\
\cline { 2 - 4 } & $\mathbf{1 \%}$ & $\mathbf{5 \%}$ & $\mathbf{1 0 \%}$ \\
\hline 10 & 10 & 10 & 10 \\
\hline 15 & 15 & 14 & 14 \\
\hline 20 & 19 & 19 & 19 \\
\hline 25 & 24 & 23 & 23 \\
\hline 35 & 33 & 32 & 31 \\
\hline 40 & 38 & 36 & 35 \\
\hline 45 & 42 & 40 & 39 \\
\hline 50 & 47 & 44 & 42 \\
\hline 55 & 51 & 48 & 46 \\
\hline 60 & 55 & 51 & 49 \\
\hline 65 & 59 & 55 & 53 \\
\hline 70 & 63 & 58 & 56 \\
\hline 75 & 67 & 62 & 59 \\
\hline 80 & 71 & 65 & 62 \\
\hline
\end{tabular}

Sumber: Data diolah

Dengan pembatasan keterbatasan jumlah sampel karena adanya kesibukan dari karyawan PT Bank Pembangunan Daerah Jawa Timur Tbk Surabaya, maka peneliti mengaju kepada Sugiyono (2018) dengan tingkat signifikan pengambilan sampel sebesar 5\%. Teknik pengambilan sampel menggunakan pendekatan yang dikembangan oleh Isaac dan Michael dalam Sugiyono (2018) dengan tingkat kesalahan atau signifikan sebesar $1 \%, 5 \%$, dan $10 \%$.

Berdasarkan Tabel 1, dapat dilihat jika jumlah populasi sebesar 75 karyawan dengan menggunakan taraf kesalahan 5\% maka sampel yang diggunakan sebanyak 62 karyawan pada PT Bank Pembangunan Daerah Jawa Timur Tbk Surabaya.

\section{Variabel Penelitian}

\section{Variabel Independen $(\mathbf{X})$}

Secara positif maupun secara negatif variabel independen adalah variabel yang mempengaruhi variabel dependen. variabel independen yang digunakan oleh penulis yaitu Orientasi CSR, Sikap dan Kompetensi.

\section{Orientasi CSR}

Orientasi CSR merupakan sebuah program yang dilaksanakan oleh PT Pembangunan Daerah Jawa Timur Tbk (Bank Jatim) untuk mengintergrasikan kepedulian sosial dan lingkungan operasi bisnis dengan para pemangku kepentingan mereka secara sukarela yang melibatkan visi dan misi dari perusahaan. Terdapat empat indikator orientasi CSR menurut Ismail et al. (2014) untuk mengukur Orientasi CSR :

1. Economic responsibility

Orientasi tanggung jawab ekonomi dianggap penting untuk mempertahankan posisi kompetitif yang kuat bagi perusahaan.

2. Philantropis responsibility

Dimana orientasi tanggung jawab filantropis dianggap sangat penting untuk dilakukan dengan cara yang konsisten melalui pelaksanaan yang sesuai dengan harapan masyarakat.

3. Legal responsibility

Orientasi tanggung jawab hukum dianggap sangat penting untuk menjadi perusahaan yang taat dengan hukum.

4. Ethical responsibility

Orientasi tanggung jawab etis dianggap sangat penting untuk dilakukan dengan cara yang konsisten dengan adat istiadat, sosial, dan norma-norma etika yang sesuai dengan harapan masyarakat.

\section{Sikap}

Sikap merupakan respon atau reaksi diri sendiri terhadap objek tertentu yang dapat bereaksi secara positif atau negatif dan memberikan pengaruh terhadap sekitarnya untuk mengumpulkan dan menggunakan informasi dalam membuat keputusan yang relevan terhadap tindakan dalam melaksanakan tugas yang berada pada PT Bank Pembangunan Daerah Jawa Timur Tbk Surabaya. Terdapat dua indikator untuk mengukur variabel sikap yang dikembangkan oleh Sim dan Lee (2018) yaitu:

1. Kepuasan kerja

Kepuasan kerja adalah keadaan emosional yang positif dari pengalaman karyawan saat bekerja.

2. Komitmen organisasi

Komitmen organisasi adalah dimana seorang karyawan telah berpihak kepada suatu organisasi berdasarkan dari nilai atau tujuan organisasi.

\section{Kompetensi}

Kompetensi adalah kemampuan, kecakapan, atau kewenangan karyawan dalam penyelesaian pekerjaan yang sesuai dengan jabatannya pada PT Bank Pembangunan Daerah Jawa Timur Tbk Surabaya. Penulis menggunakan tiga indikator untuk mengukur 
kompetensi yang dikembangkan oleh Ismail et al. (2014) yaitu :

1. Kompetensi teknis

Kompetensi teknis berhubungan dengan produk dan proses perusahaan, seperti keterampilan yang memungkinkan aplikasi komputer dan pemecahan sistematis masalah dalam kenyataan dengan menjembatani kesenjangan digital.

2. Kompetensi komunikasi

Kompetensi komunikasi berhubungan dengan kemampuannya untuk berbicara, berdiskusi, bernegosiasi dan membujuk klien untuk melaksanakan kegiatan sehari-hari.

3. Kompetensi kewirausahaan

Kemampuan kewirausahaan sangat relevan bagi kinerja pemasaran, keterampilan kewirausahaan juga mencakup keterampilan teknis, terutama dalam kaitannya dengan pengolahan dari sebuah produk manufaktur dan pemasarannya.

\section{Variabel Dependen (Y)}

Penulis menggunakan variabel dependen yaitu peran karyawan yang berada di PT Bank Pembangunan Daerah Jawa Timur Tbk (Bank Jatim) Surabaya. Peran merupakan tingkah laku yang dimiliki oleh karyawan yang menempati suatu kedudukan atau jabatan dan dapat memberikan pengaruh kepada organisasi untuk mewujudkan arah dan tujuan dari perusahaan. Dalam penelitian ini indikator yang digunakan sebagai tolak ukur variabel peran menurut Tjahjono (2006) adalah:

1. Strategi SDM

Menyamakan strategi dan dengan tujuan bisnis perusahaan adalah peran dari sumber daya manusia.

2. Transformasi dan perubahan

Transformasi meliputi perubahan budaya yang terjadi dalam perusahaan, perubahan mengarah kepada kemampuan untuk menciptakan ide-ide baru atau inspirasi dalam setiap penerapan proses perusahaan

3. Kontribusi Karyawan

Adanya permasalahan didunia kerja membuat karyawan harus berkontribusi serta peduli dan memperhatikan kebutuhan setiap karyawan. karyawan

4. Infrastruktur perusahaan

Insfrastruktur organisasi adalah peran dari tanggung jawab SDM dalam menjalankan proses-proses organisasi secara efektif seperti, staffing, training, hadiah, penghargaan, dan promosi.

\section{Teknik Pengumpulan Data Kuisioner}

Kuesioner dalam penelitian ini berupa pernyataan yang harus dijawab oleh responden penelitian. Hasil dari penelitian akan bergantung pada jawaban dari kuesioner yang telah dijawab oleh responden. Kuisioner sangat cocok untuk digunakan apabila jumlah responden cukup besar.

\section{Teknik Analisis \\ Uji Validitas}

Valid atau tidaknya kuesioner dapat diketahui melalui uji validitas. Ketika kuesioner mampu mengungkap maksud dari apa yang ingin diukur maka dapat dikatakan jika kuesioner tersebut telah valid. Uji validitas dapat dilakukan dengan cara melihat nilai AVE model harus lebih dari 0,05 (Ghozali, 2018).

\section{Uji Reliabilitas}

Menurut Ghozali (2018:45) uji reabilitas digunakan untuk mengukur suatu kuisioner yang merupakan indikator dari variabel atau konstruk, jika jawaban dari seorang responden sudah konsisten atau stabil maka dapat dikatakan kuisioner sudah reliabel, dan sebaliknya jika responden menjawab pertanyaan secara acak maka dapat dikatan belum reliabel. Riduwan, Rusyana, dan Enas (2011) menyatakan tingkat reabilitas dilihat dari nilai Cronbach's Alpha dengan beberapa syarat yang dapat dilihat pada Tabel 2 .

\section{Tabel 2}

\section{Tingkat Reabilitas Dilihat Dari Nilai Alpha}

\begin{tabular}{cc}
\hline $\begin{array}{c}\text { Nilai } \\
\text { Cronbach's Alpha }\end{array}$ & $\begin{array}{c}\text { Tingkat } \\
\text { Reabilitas }\end{array}$ \\
\hline $0,0-0,20$ & $\begin{array}{c}\text { Kurang } \\
\text { Reliabel }\end{array}$ \\
\hline$>0,20-0,40$ & Agak Reliabel \\
\hline$>0,40-0,60$ & $\begin{array}{c}\text { Cukup } \\
\text { Reliabel }\end{array}$ \\
\hline$>0,60-0,80$ & Reliabel \\
\hline$>0,80-1,00$ & $\begin{array}{c}\text { Sangat } \\
\text { Reliabel }\end{array}$ \\
\hline
\end{tabular}

Sumber: Riduwan, Rusyana, dan Enas (2011)

\section{Analisis Statistik Deskriptif}

Analisis ini berguna untuk menggambarkan hasil dari data yang telah terkumpul dan kemudian ditarik kesimpulan yang dapat berlaku untuk umum. Manurut Azwar (2012) untuk membuat kategori data adalah dengan terlebih dahulu membuat kriterianya dan juga berapa jumlah kategori yang akan dibuat, dalam penelitian ini 
kategorisasi berjumlah tiga (rendah, sedang, dan tinggi).

\section{Analisis Statistik Inferensial}

Sugiyono (2018) menyatakan bahwa statistik inferensial adalah teknik statistik yang digunakan untuk menganalisis data sampel yang hasilnya digunakan untuk populasi. Statistik inferensial cocok untuk digunakan apabila sampel yang diambil jelas dan mencakup semua populasi.

\section{Partial Least Square (PLS)}

Hipotesis penelitian ini dilakukan dengan metode analisis Partial Least Square (PLS) dengan pendekatan Structural Equation Model (SEM) yang didukung dengan software aplikasi smartPLS. PLS merupakan metode analisis yang dapat gunakan ketika jumlah sampel tidak harus besar dan bisa mencakup semua skala.

Monecke dan Leisch (2012) menyatakan beberapa peniliti yang memiliki variabel atau konstruk seperti ambiguitas, peran, dan sikap cenderung menggunakan SEM sebagai teknik analisis yang digunakan, karena SEM dirancang untuk bekerja dengan banyak persamaan yang terkait secara bersama-sama dan memberikan berbagai macam keunggulan dibandingkan dengan yang lainnya.

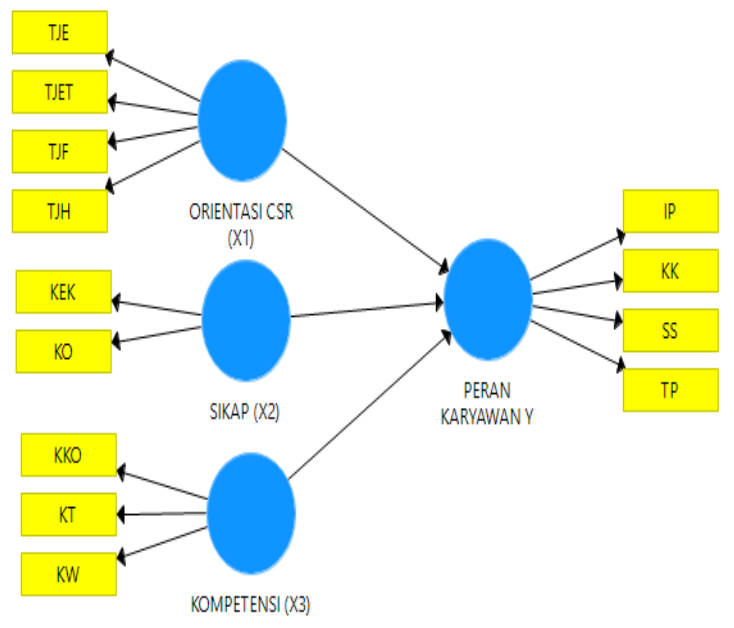

Gambar 3

Rancangan Model Pengukuran

Sumber: SmartPls v.3.2.8 (2019)

\section{Estimasi}

Metode estimasi ini merupakan perhitungan secara iterasi, jika kondisi konvergen telah tercapai maka iterasi akan berhenti. Metode ini adalah estimasi pada PLS dengan least square methods.

\section{Converget Validity}

Nilai yang harus diperoleh dari loading ini adalah 0,05 sampai 0,06 sehingga nilai akan dikatakan cukup. Ini merupakan hubungan antara indikator refleksif dengan skor variabel latennya (Chin 1998 dalam Ghozali 2018).

\section{Discriminant Validity}

Pada tahap ini nilai square root of average variance extracted (AVE) akan dibandingan dengan konstruk yang ada pada model lain. AVE dikatakan baik jika memiliki nilai lebih besar dari hubungan semua konstruk yang ada. Direkomendasikan nilai pengukuran harus lebih besar dari 0.50 (Chin 1998 dalam Ghozali 2018).

\section{Composite Reliability}

Nilai pada reabilitas composit harus lebih dari 0,70. Ini merupakan reabilitas untuk mengukur kelompok indikator pada sebuah variabel (Chin 1998 dalam Ghozali 2018).

\section{Inner Model}

R-Square digunakan untuk mengukur Goodnes of fit model model variabel laten menggunakan interpretasi yang sama dengan regresi. Nilai Q-square $>0$ berarti model memiliki predictive relevance dan apabila nilai $\mathrm{Q}$-square $\leq 0$ maka dapat dikatakan model kurang memiliki predictive relevance.

\section{Pengujian Hipotesis}

Pengujian hipotesis penelitian dilakukan dengan melihat dari koefisien jalur dan membandingkan dengan nilai probabilitas 0.05 . apabila nilai sig $<0,05$ maka artinya hipotesis tidak signifikan atau $\mathrm{H} 0$ diterima dan jika nilai sig $>0,05$ maka hipotesis signifikan atau $\mathrm{H} 1$ diterima.

\section{PEMBAHASAN \\ Karakteristik Responden}

Pada Tabel 3 dijelaskan, terdapat 36 atau $66,7 \%$ responden dengan usia 21-30 tahun. Sebanyak 14 atau $25,9 \%$ adalah responden dengan usia 31-40 tahun. Dan sebanyak 4 atau 7,4\% responden dengan usia $>40$ tahun. Hasil tersebut menunjukkan bahwa dominan responden pada Bank Jatim adalah karyawan berusia 21-30 tahun sebanyak 36 orang atau $66,7 \%$.

Pada Tabel 3 dijelaskan bahwa terdapat 31 orang atau $57,4 \%$ responden berjenis kelamin lakilaki, dan 23 atau $42,6 \%$ responden berberjenis kelamin perempuan. Hasil tersebut menunjukkan bahwa dominan responden pada Bank Jatim adalah 
karyawan yang memiliki jenis kelamin laki-laki dengan 31 atau $57,4 \%$ responden.

\section{Tabel 3}

Karakteristik Responden

\begin{tabular}{|c|c|c|c|}
\hline \multirow{2}{*}{ No } & \multirow{2}{*}{$\begin{array}{c}\text { Karakteristik } \\
\text { Responden }\end{array}$} & \multicolumn{2}{|c|}{ Karyawan } \\
\hline & & $\mathrm{F}$ & $\%$ \\
\hline \multirow{4}{*}{1} & Usia & & \\
\hline & 20 sampai 30 & 36 & 66,7 \\
\hline & 31 sampai 40 & 14 & 25,9 \\
\hline & $>40$ & 4 & 7,4 \\
\hline \multirow{3}{*}{2} & Jenis kelamin & & \\
\hline & Laki- laki & 31 & 57,4 \\
\hline & Perempuan & 23 & 42,6 \\
\hline \multirow{5}{*}{3} & Pendidikan & & \\
\hline & Terakhir & & 37 \\
\hline & SLTA & $\begin{array}{l}2 \\
3\end{array}$ & $\begin{array}{l}5,1 \\
5,6\end{array}$ \\
\hline & D3 & $\begin{array}{c}5 \\
46\end{array}$ & 85,2 \\
\hline & $\begin{array}{l}\text { S1 } \\
\text { S2 }\end{array}$ & 3 & 5,6 \\
\hline \multirow{3}{*}{4} & Status Pernikahan & & \\
\hline & Menikah & 34 & 63,3 \\
\hline & Belum menikah & 20 & 37,0 \\
\hline \multirow{4}{*}{5} & Masa kerja & & \\
\hline & $1-5$ & 33 & 61,1 \\
\hline & $6-10$ & 15 & 27,8 \\
\hline & $>10$ & 6 & 11,1 \\
\hline
\end{tabular}

Sumber: Hasil SPSS Versi 25 (2019)

Pada Tabel 3 dijelaskan bahwa terdapat 2 atau $3,7 \%$ responden yang memiliki tingkat pendidikan SLTA. 3 orang atau 5,6\% responden dengan pendidikan D3. 46 orang atau $85,2 \%$ responden dengan pendidikan S1. Dan 3 orang atau $5,6 \%$ karyawan dengan pendidikan S2. Hasil tersebut menunjukkan bahwa dominan responden pada Bank Jatim adalah karyawan yang memiliki pendidikan S1 dengan 46 atau 85,2\% responden.

Pada Tabel 3 dijelaskan bahwa terdapat 34 atau $63,0 \%$ responden yang sudah menikah dan terdapat 20 atau $37,0 \%$ responden yang belum menikah. Hal tersebut menunjukkan bahwa dominan responden pada Bank Jatim adalah karyawan yang sudah menikah dengan jumlah 34 atau 63,0\% responden.

Pada Tabel 3 dapat dijelaskan bahwa terdapat 33 atau $61,1 \%$ responden dengan masa kerja selama 1-5 tahun. 15 orang atau $27,8 \%$ responden dengan masa kerja selama 6-10 tahun. 6 orang atau $11,1 \%$ responden dengan masa kerja $>10$ tahun. Hasil tersebut menunjukkan bahwa dominan responden pada Bank Jatim dengan masa kerja 1-5 tahun sebanyak 33 atau $61,1 \%$ responden.

\section{Statistik deskriptif}

Pada Tabel 4 hasil statistik dari penilaian responden terhadap orientasi CSR yang memiliki skor skala tinggi dengan frekuensi $47(87,0 \%)$, dan skor skala sedang dengan frekuensi $7(13,0 \%)$. Dari hasil tersebut menunjukkan bahwa dominan frekuensi kategori tinggi dengan 47 responden atau $87,0 \%$ dan tidak ada yang memiliki skor skala yang rendah.

\section{Tabel 4}

Penilaian Responden Penelitian Mengenai Orientasi CSR

\begin{tabular}{llccc}
\hline \multirow{2}{*}{ Valid } & & F & Percent & $\begin{array}{c}\text { Valid } \\
\%\end{array}$ \\
\cline { 2 - 5 } & Sedang & 7 & 13,0 & 13,0 \\
\cline { 2 - 5 } & Tinggi & 47 & 87,0 & 87,0 \\
\cline { 2 - 5 } & Total & 54 & 100,0 & 100,0 \\
\hline
\end{tabular}

Sumber : Hasil SPSS Versi 25 (2019)

Pada Tabel 5 hasil statistik dari penilaian responden terhadap sikap yang memiliki skor skala tinggi dengan frekuensi $24(44,4 \%)$, skor skala sedang dengan frekuensi $26(48,1 \%)$, dan skor skala rendah dengan rendah $4(7,4)$. berdasarkan hasil tersebut menunjukkan bahwa dominan frekuensi kategori sedang dengan 26 responden atau $48,1 \%$.

\section{Tabel 5}

Penilaian Responden Penelitian Mengenai Sikap

\begin{tabular}{ccccc}
\hline \multirow{2}{*}{ Valid } & F & Percent & $\begin{array}{c}\text { Valid } \\
\%\end{array}$ \\
\cline { 2 - 5 } & Rendah & 4 & 7,4 & $\begin{array}{c}7,4 \\
48,1\end{array}$ \\
\cline { 2 - 5 } & Sedang & 26 & 48,1 & 48,1 \\
\cline { 2 - 5 } & Tinggi & 24 & 44,4 & 44,4 \\
\cline { 2 - 5 } & Total & 54 & 100,0 & 100,0 \\
\hline
\end{tabular}

Sumber : Hasil SPSS Versi 25 (2019)

Pada Tabel 6 hasil statistik penilaian responden terhadap kompetensi yang memiliki skor skala tinggi dengan frekuensi $3(5,6 \%)$, skor skala sedang dengan frekuensi $48(88,9 \%)$, dan skor skala rendah dengan frekuensi $3(5,6 \%)$. Dari hasil tersebut penilaian responden yang mendominasi adalah skala sedang dengan frekuensi 48 responden atau $88,9 \%$. 
Tabel 6

Penilaian Responden Penelitian Mengenai Kompetensi

\begin{tabular}{ccccc}
\hline \multirow{2}{*}{ Valid } & & F & Percent & $\begin{array}{c}\text { Valid } \\
\%\end{array}$ \\
\cline { 2 - 5 } & Rendah & 3 & 5,6 & 5,6 \\
\cline { 2 - 5 } & Sedang & 48 & 88,9 & 88,9 \\
\cline { 2 - 5 } & Tinggi & 3 & 5,6 & 5,6 \\
\cline { 2 - 5 } & Total & 54 & 100,0 & 100,0 \\
\hline & Sumber : Hasil SPSS Versi 25 (2019)
\end{tabular}

Pada Tabel 7 hasil statistik penilaian responden terhadap peran karyawan yang memiliki skor skala tinggi dengan frekuensi 49 (90,7\%), skor skala sedang dengan frekuensi 5 (9,3\%). Dari hasil tersebut terlihat bahwa penilaian responden terhadap variabel peran karyawan tidak memiliki skor skala yang rendah dan didominasi oleh frekuensi tinggi dengan 49 responden atau 90,7\%.

Tabel 7

Penilaian Responden Penelitian Mengenai Peran Karyawan

\begin{tabular}{ccccc}
\hline & & F & Percent & $\begin{array}{c}\text { Valid } \\
\%\end{array}$ \\
\hline \multirow{3}{*}{ Valid } & Sedang & 5 & 9,3 & 9,3 \\
\cline { 2 - 5 } & Tinggi & 49 & 90,7 & 90,7 \\
\cline { 2 - 5 } & Total & 54 & 100,0 & 100,0 \\
\hline
\end{tabular}

Sumber : Hasil SPSS Versi 25 (2019)

\section{Convergent Validity}

Gambar 4 memperlihatkan jumlah loading faktor dari uji measurment terhadap empat variabel (orientasi CSR, sikap, kompetensi, dan peran karyawan).

\section{Tabel 8}

\section{Outer Loading Variabel Orientasi CSR}

\begin{tabular}{lcc}
\hline Item & Outer Loading & Keterangan \\
\hline TJE & 0,988 & Valid \\
\hline TJET & 0.991 & Valid \\
\hline TJF & 0.981 & Valid \\
\hline TJH & 0.952 & Valid \\
\hline \multicolumn{2}{c}{ Sumber Output SmartPLS } & $3.2 .8(2019)$
\end{tabular}

Berdasrkan Tabel 8 menunjukkan nilai outer loading dari masing-masing indikator orientasi CSR menunjukkan angka lebih dari 0,70 maka dapat dikatakan semua indikator dari orientasi CSR adalah valid.

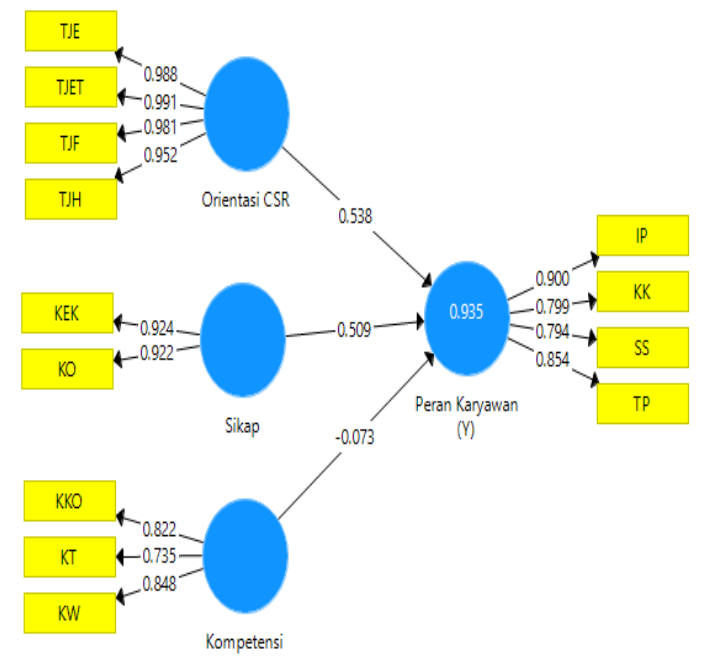

Gambar 4

Uji Measurement Model

Sumber Output SmartPLS 3.2.8 2019

Tabel 9

Outer Loading Variabel Sikap

\begin{tabular}{lcc}
\hline Item & Outer Loading & Keterangan \\
\hline KEK & 0,924 & Valid \\
\hline KO & 0,922 & Valid \\
\hline \multicolumn{2}{c}{ Sumber : Output SmartPLS } & $3.2 .8(2019)$
\end{tabular}

Berdasrkan Tabel 9 menunjukkan nilai outer loading dari masing-masing indikator variabel sikap menunjukkan angka > 0,70 maka dikatakan semua indikator dari variabel sikap adalah valid.

\section{Tabel 10}

Outer Loading Variabel Kompetensi

\begin{tabular}{ccc}
\hline Item & Outer Loading & Keterangan \\
\hline KKO & 0,822 & Valid \\
\hline KT & 0,735 & Valid \\
\hline KW & 0,848 & Valid \\
\hline
\end{tabular}

Sumber : Output SmartPLS 3.2.8 (2019)

Berdasrkan Tabel 10 menunjukkan nilai outer loading dari masing-masing indikator variabel kompetensi menunjukkan angka >0,70 maka dapat dikatakan semua indikator dari variabel kompetensi adalah valid.

Berdasrkan Tabel 11 menunjukkan nilai outer loading dari masing-masing indikator variabel peran karyawan menunjukkan angka $>0,70$ maka dapat dikatakan semua indikator dari variabel peran karyawan adalah valid. 
Tabel 11

Outer Loading Variabel Peran Karyawan

\begin{tabular}{ccc} 
Item & Outer Loading & Keterangan \\
IP & 0,900 & Valid \\
KK & 0,799 & Valid \\
SS & 0,794 & Valid \\
TP & 0,854 & Valid \\
\hline
\end{tabular}

Sumber: Output SmartPLS 3.2.8 (2019)

\section{Composite Reability}

Pada Tabel 12, menunjukkan nilai composite reability $>0,70$, maka dapat dikatakan model variabel memiliki reabilitas yang cukup baik.

Tabel 12

\begin{tabular}{ccc}
\multicolumn{3}{c}{ Composite Reability Variabel } \\
\hline Variabel & $\begin{array}{c}\text { Composite } \\
\text { Reability }\end{array}$ & Keterangan \\
\hline $\begin{array}{c}\text { Orientasi CSR } \\
\text { (X1) }\end{array}$ & 0,989 & Reliabel \\
\hline Sikap (X2) & 0,920 & Reliabel \\
\hline $\begin{array}{c}\text { Kompetensi } \\
\text { (X3) }\end{array}$ & 0.845 & Reliabel \\
\hline $\begin{array}{c}\text { Peran Karyawan } \\
\text { (Y) }\end{array}$ & 0,904 & Reliabel \\
\hline
\end{tabular}

Sumber : Output SmartPLS 3.2.8 (2019)

\section{Cronbach's Alpha}

Nilai Croanbach's alpha bisa dikatakan cukup reliabel apabila >0,40-0,60, dikatakan reliabel apabila $>0,60-0,80$, dan dikatakan sangat reliabel apabila >0,80-1,00 (Riduwan,Rusyana, dan Enas, 2011). Pada Tabel 13 menunjukkan bahwa nilai cronbach's alpha dari orientasi CSR, sikap dan peran karyawan dikatakan sangat reliabel, sedangkan kompetensi dikatakan reliabel reliabel.

Tabel 13

\begin{tabular}{cc} 
Cronbach's Alpha Variabel \\
\hline Variabel & $\begin{array}{c}\text { Cronsbach's } \\
\text { Alpha }\end{array}$ \\
\hline Orientasi CSR (X1) & 0,985 \\
\hline Sikap (X2) & 0,826 \\
\hline Kompetensi (X3) & 0,727 \\
\hline Peran Karyawan (Y) & 0,856 \\
\hline
\end{tabular}

Sumber: Output SmartPLS 3.2.8 (2019)

\section{Analisis R-Square}

Pada Tabel 14, pengaruh orientasi CSR, Sikap, dan Kompetensi terhadap Peran karawan menunjukkan nilai R-Square sebesar 0,935 dan dapat dijelaskan bahwa variabel peran karyawan mampu dijelaskan oleh variabel orientasi CSR, sikap, dan kompetensi sebesar 93\% sedangkan peran karyawan dapat dijelaskan dengan variabel yang tidak ada pada penelitian ini sebesar $7 \%$.

\section{Tabel 14}

Nilai R-Square Model

\begin{tabular}{cc}
\hline Variabel & R-Square \\
\hline Orientasi CSR (X1) & \\
Sikap (X2) & \\
Kompetensi (X3) & 0,935 \\
Peran Karyawan (Y) & \multicolumn{2}{c}{ Sumber : Output SmartPLS 3.2.8 (2019) }
\end{tabular}

\section{Uji Relevansi Prediksi}

Berikut ini merupakan perhitungan dari nilai Q-square predictive relevance pada model penelitian ini:

$$
\begin{aligned}
& =1-\left(\sqrt{ } 1-\mathrm{R} 1^{2}\right) \\
& =1-\left(\sqrt{ } 1-0,935^{2}\right) \\
& =1-(0,354) \\
& =0,645
\end{aligned}
$$

Dari perhitungan tersebut diperoleh nilai sebesar 0,645 yang berarti $>0$ hal itu dapat menjelaskan model sebesar $64 \%$.

\section{Uji Kausalitas}

Tabel 15

Hasil Path Coefficents

\begin{tabular}{ccccc}
\hline $\begin{array}{c}\text { Hubungan Antar } \\
\text { Variabel }\end{array}$ & $\begin{array}{c}\text { Original } \\
\text { Sample }\end{array}$ & T-Statistics & Keterangan & Kesimpulan \\
\hline $\begin{array}{c}\text { Orientasi CSR } \rightarrow \\
\text { Peran Karyawan }\end{array}$ & 0,538 & 3,327 & $\begin{array}{c}\geq 1,96 \\
\text { (Signifikan) }\end{array}$ & $\begin{array}{c}\text { Hipotesis } \\
\text { diterima }\end{array}$ \\
\hline $\begin{array}{c}\text { Sikap } \rightarrow \text { Peran } \\
\text { Karyawan }\end{array}$ & 0,509 & 4,942 & $\begin{array}{c}\geq 1,96 \\
\text { (Signifikan) }\end{array}$ & $\begin{array}{c}\text { Hipotesis } \\
\text { diterima }\end{array}$ \\
\hline $\begin{array}{c}\text { Kompetensi } \rightarrow \\
\text { Peran Karyawan }\end{array}$ & $-0,073$ & 0,671 & $\begin{array}{c}\geq 1,96 \text { (Tidak } \\
\text { Signifikan) }\end{array}$ & $\begin{array}{c}\text { Hipotesis } \\
\text { ditolak }\end{array}$ \\
\hline Selation
\end{tabular}

Sumber : Output SmartPLS 3.2.8 (2019)

Tabel 15 menunjukkan nilai $t$-statistics orientasi CSR memiliki pengaruh signifikan terhadap peran karyawan sebesar $3.327>1,96$. Maka dapat dikatakan bahwa semakin tinggi orientasi CSR maka peran karyawan juga semakin tinggi.

Besarnya nilai $t$-statistics menunjukkan sikap memiliki pengaruh signifikan terhadap peran karyawan sebesar $4.942>1,96$. Maka dapat dikatakan bahwa semakin tinggi sikap maka peran karyawan akan semakin tinggi.

Besarnya nilai t-statistics menunjukkan kompetensi tidak memiliki pengaruh yang signifikan terhadap peran karyawan sebesar 0,671 $<1,96$. Hal tersebut menunjukkan apabila semakin tinggi atau semakin rendah kompetensi maka tidak akan berdampak pada peran karyawan. Kompetensi menggunakan tiga indikator dari Ismail (2014) yaitu kompetensi teknis, kompetensi 
kewirausahaan, dan kompetensi komunikasi. Berdasarkan hasil nilai t-statistik dari kompetensi sebesar 0,098 < 1,65 maka H3 ditolak. Artinya pengujian menunjukkan bahwa kompetensi tidak mempengaruhi peran karyawan secara signifikan positif.

Hasil ini berbeda dengan penelitian terdahulu yang dilakukan oleh Ismail (2014), Malik (2014), dan Suryaningtyas (2013) yang menyatakan bahwa kompetensi berpengaruh positif terhadap peran karyawan. Hasil penelitian ini berbeda dengan penelitian sebelumnya dikarenakan dalam penelitian Ismail (2014) mendapatkan frekuensi jawaban yang tinggi dari semua pernyataan yaitu 16 item serta manajer sangat mementingkan kompetensi karyawan terlebih dahulu sebelum mementingkan aspek-aspek lain seperti sikap.

Penelitian Malik (2014) memiliki jumlah responden sebanyak 46 orang dengan jabatan yang tinggi, ada 34 responden yang memiliki jabatan sebagai manajer, 10 responden memiliki jabatan sebagai supervisor serta ada 2 staf keuangan. Dari rata-rata jawaban responden memiliki nilai yang tinggi hal itu berarti semua responden memiliki kompetensi yang baik dan mempengaruhi kegiatan dalam bisnis. Deskriptif responden mendukung penelitian ini dimana variabel kompetensi memiliki dominan frekuensi tertinggi pada kategori sedang dengan 79 orang atau 91\%, kategori tinggi hanya 6 orang atau 7,0\%, bahkan responden juga memiliki frekuensi dengan kategori rendah yaitu 1 orang atau $1,2 \%$.

Hasil ini juga didukung dari adanya fenomena yang terjadi di PT Bank Pembangunan Daerah Jawa Timur Tbk yaitu kurangnya kompetensi komunikasi karyawan. Selain itu berdasarkan dari jawaban kuesioner responden yang telah terkumpul yang memiliki skor terendah, perusahaan dianggap kurang melibatkan staf dalam proses perencanaan program kerja diperusahaan, program kerja yang telah ada dianggap kurang jelas, kurangnya tindakan dan aktivitas karyawan dalam kegiatan berkelompok atau kerja tim, penyampaian tujuan yang kurang jelas dari atasan dan penyaluran beban kerja terhadap karyawan yang kurang merata.

Berdasarkan hasil tersebut disimpulkan bahwa kompetensi tidak mempunyai pengaruh pada peran karyawan karena hasil penelitian tidak menunjukkan adanya hubungan yang signifikan. Maka dapat dikatakan semakin rendah atau tinggi kompetensi karyawan tidak akan berdampak atau berpengaruh terhadap peran karyawan.

\section{PENUTUP}

\section{Kesimpulan}

Orientasi CSR secara signifikan positif mempengaruhi peran karyawan. Hal tersebut menunjukkan bahwa jika orientasi CSR di perusahaan tinggi maka akan meningkatkan peran karyawan. Sikap secara signifikan mempengaruhi peran karyawan. Hal tersebut menunjukkan bahwa jika sikap karyawan di perusahaan tinggi maka peran karyawan akan semakin tinggi. Kompetensi tidak memiliki pengaruh yang signifikan terhadap peran karyawan. Hal tersebut menunjukkan bahwa semakin tinggi atau rendah kompetensi maka tidak akan berdampak pada peran karyawan.

\section{Keterbatasan dan Rekomendasi untuk Peneliti Selanjutnya}

Penelitian ini hanya meneliti pengaruh orientasi CSR terhadap peran karyawan, sikap terhadap peran karyawan, dan kompetensi terhadap peran karyawan pada divisi corporate secretary, pengendalian keuangan, kepatuhan dan tata kelola pada PT Bank Pembangunan Daerah Jawa Timur Tbk Surabaya. Oleh karena itu, peneliti merekomendasikan untuk penelitian selanjutnya agar bisa meneliti seluruh divisi dari PT Bank Pembangunan Daerah Jawa Timur Tbk Surabaya.

Sektor industri merupakan sektor kekuatan strategis dan terbukti memberikan kontribusi signifikan terhadap PDB (Produk Domestik Bruto) dan penyerapan tenaga kerja. Produk Domestik Bruto (PDB) didefinisikan sebagai total nilai atau harga pasar (market prices) dari seluruh barang dan jasa akhir (final goods and services) yang dihasilkan oleh suatu perekonomian selama kurun waktu tertentu. Produk Domestik Bruto merupakan indikator penting untuk mengetahui kondisi ekonomi di suatu negara. Apabila PDB suatu negara meningkat, maka dapat dikatakan bahwa perekonomian negara tersebut menjadi lebih baik dari tahun sebelumnya.

\section{DAFTAR PUSTAKA}

Ahtobara, Dewi Mulyasari. Holilulloh, M. and Adha, M. Mona. 2013. Faktor-Faktor yang Mempengaruhi Terbentuknya Peran Perempuan Dalam Meningkatkan Penghasilan Rumah Tangga Melalui Sektor Formal dan Informal di Desa Purworejo Kabupaten Pesawaran Tahun 2012. pp. 116.

Alonso, A. D. and Austin, I. P. 2018. Competitiveness Review: An International Business Journal changes publisher, 
Competitiveness Review. 17(1/2), pp. 1-22.

Amanto, A. D. (2011). Hubungan Bimbingan di Industri Terhadap Sikap Kerja Siswa Kelas III Jurusan Teknik Kendaraan Ringan SMK N 1 Seyegan. pp. 1-115.

Azwar, S. 2012. Penyususnan Skala Psikologi edisi 2. Pustaka Belajar.

Carroll, A. B. and Shabana, K. M. 2010. The Business Case for Corporate Social Responsibility: A Review of Concepts, Research and Practice. Journal of Management Riviews Management Riviews. pp. 85-105.

Dahlsrud, A. (2008) How Corporate Social Responsibility is Defined : an Analysis of 37 Definitions. Corporate Social Responsibility and Environmental Management. 13 (November 2006). pp. 1-13.

Diez, J. L. G., Gago, R. F. and Campillo, A. M. 2011. How Important Are CEOs to CSR Practices? An Analysis of the Mediating Effect of the Perceived Role of Ethics and Social Responsibility. Journal of Business Ethics. 98(4), pp. 531-548.

Duthler, G. and Dhanesh, G. S. 2018. The role of corporate social responsibility (CSR) and internal CSR communication in predicting employee engagement: Perspectives from the United Arab Emirates (UAE). Public Relations Review. Elsevier. 44(4), pp. 453462.

Egri, C. P. and Susan Herman 2000. Leadership in The North American Environmental Sector : Values, Leadership Styles, and Contexts Leaders and of Environmental Leadership and their Organization. Academy of Management. 43(4), pp. 571-604.

Fernandez, E., Junquera, B. and Ordiz, M. 2006. Managers 'Profile in Environmental Strategy: A Review of the Literature. Corporate Social Responsibility and Environmental Management. 274 (June), pp. 261-274.

Ghozali, I. 2018. Aplikasi Analisis Multivariated Dengan Program IBM SPSS 25. 9th edn. Semarang.

Howe, L. C. and Krosnick, J. A. 2017. Attitude Strength. (August 2016), pp. 1-25. doi: 10.1146/annurev-psych-122414-033600.

Ionescu, E., Merut, A. and Dragomiroiu, R. 2014. Role of Managers in Management of Change. Procedia Economics and Finance. 16 (May), pp. 293-298.

Ismail, M., Kassim, M. I., et al. 2014. Orientation,
Attitude, and Competency as Predictors of Manager's Role of CSR- Implementing Companies in Malaysia. European Journal of Training and Development. 38 no.5, pp. 415-435.

Ismail, M., Johar, R. F. A., et al. 2014. School as Stakeholder of Corporate Social Responsibility Program: Teacher's Perspective on Outcome in School Development. Professional Development and Continuing Education. 23, pp. 321-331.

Jamali, D. 2007. The Case for Strategic Corporate Social Responsibility in Developing Countries. Business and Society Review. 112(1), pp. 1-27.

Khoshouei, M. S., Oreyzi, H. R. and Noori, A. 2013. The Eight Managerial Competencies: Essential Competencies for Twenty First Century Managers. Iranian Journal of Management Studies (IJMS). 66 (22), pp. 131-152.

Kohont, A. and Brewster, C. 2014. The roles and competencies of HR managers in Slovenian multinational companies. Baltic Journal of Management. 9 (3), pp. 294-313.

Monecke, A. and Leisch, F. 2012. semPLS: Structural Equation Modeling Using Partial Least Squares. Journal of Statistical Software. 48 (3).

Nansubuga, F. and Munene, J. C. 2013. Reflecting on competences to increase role clarity during service delivery in a Third World setting. Journal of Workplace Learning. 25 (4), pp. 231-246.

Podmetina, D. et al. 2018. Developing a competency model for open innovation From the individual to the organisational level.

Rashid, Z. A. and Ibrahim, S. 2002. Executive and management attitudes towards corporate social responsibility in Malaysia. pp. 10-16. doi: 10.1108/14720700210447641.

Riduwan, Rusyana and Enas 2011. Cara Mudah Belajar SPSS 17.0 dan Aplikasi Statistik Penelitian.

Ruzgar, N. and Kurt, M. 2013. Evidence from Bursa. Procedia - Social and Behavioral Sciences. Elsevier B.V., 99, pp. 240-246. Available at: 491.

Saidi, M. I. et al. 2014. Defining HR Roles of Nursing Line Manager in Workplace Learning. Procedia - Social and Behavioral Sciences. Elsevier B.V., 129 (October 2012), pp. 148-155.

Scholmerich, M. J. 2013. On the Impact of 
Corporate Social Responsibility on Poverty in Cambodia in The Light of Sen's Capability Approach. Asian J Bus Ethics. 2. pp. 1-33.

Sim, Y. and Lee, E. 2018. Perceived underqualification and job attitudes: the role of transformational leadership and leadership. Leadership \& Organization Development Journal. doi: 10.1108/LODJ03-2018-0127.

Siregar, S. 2014. Statistik Parametrik untuk Penelitian Kuantitatif: Dilengkapi Dengan Perhitungan Manual dan Aplikasi SPSS versi 17. Edisi 1. Jakarta: Bumi Angkasa.

Skorkova, Z. 2016. Competency models in public sector. Procedia - Social and Behavioral Sciences. The Author(s), 230 (May), pp. 226-234.
Sugiyono 2018. Metode penelitian kuantitatif, kualitatif, dan $R \& D$. 27th edn. Bandung: Alfabeta.

Suryaningtyas, D. 2013. Analisis Pengaruh Kompetensi Terhadap Peran-Peran Baru Profesional Sumber Daya Manusia. 9 no.3, pp. 169-190.

Tjahjono, H. K. 2006. Peran-peran Sumber Daya Manusia Telaah Konsepsual dan Validasi Empiris. Kompak. pp. 143-158.

Voermans, M. and Van Veldhoven, M. 2007. Attitude towards E-HRM: An empirical study at Philips. Personnel Review. 36 (6), pp. 887-902.

Yoon, J. and Lee, S. 2016. What makes employees zealous supporters of their firm's CSR initiative? The role of employees' perceptions of their firm's CSR authenticity. Advances in Group Processes. 33, pp. 93126. 